\title{
Implikasi Penerapan Undang-Undang Nomor 11 Tahun 2016 Tentang Pengampunan Pajak (Tax Amnesty) Dalam Meningkatkan Kepatuhan Wajib Pajak
}

\author{
oleh : \\ Agus Saiful Abib, Efi Yulistyowati, Amri Panahatan Sihotang. \\ Dosen Fakultas Hukum Universitas Semarang \\ agus_saifulabib@yahoo.com, efiyulistyowati@gmail.com, amri@ymail.com
}

\begin{abstract}
Abstrak
Tahun 2016, pemerintah mengeluarkan kembali kebijakan Tax Amnesty yang dituangkan dalam Undang-Undang Nomor 11 Tahun 2016 tentang Pengampunan Pajak. Pengampunan Pajak (Tax Amnesty) ini diharapkan dapat meningkatkan penerimaan pajak dalam jangka pendek melalui pembayaran uang tebusan, meningkatkan penerimaan pajak dalam jangka panjang melalui perluasan basis data pemajakan, meningkatkan kepatuhan Wajib Pajak, transisi ke sistem perpajakan baru yang lebih kuat dan adil, dan mendorong rekonsiliasi perpajakan nasional. Sehubungan dengan hal tersebut, untuk mengetahui apakah program Tax Amnesty Indonesia Tahun 2016 berhasil atau tidak, khususnya dalam meningkatkan kepatuhan wajib pajak, maka perlu dilakukan penelitian tentang : "Implikasi Penerapan Undang-Undang Nomor 11 Tahun 2016 tentang Pengampunan Pajak (Tax Amnesty) dalam Meningkatkan Kepatuhan Wajib Pajak". Adapun permasalahan yang akan dibahas adalah bagaimana implikasi penerapan Undang-Undang Nomor 11 Tahun 2016 tentang Pengampunan Pajak (Tax Amnesty) dalam meningkatkan kepatuhan Wajib Pajak ? Berdasarkan implikasi tersebut, maka bagaimana sebaiknya pengaturan perpajakan yang akan datang ? Berdasarkan permasalahan tersebut jenis penelitian ini adalah yuridis normatif yang akan dikaji dengan pendekatan perundang-undangan, spesifikasi penelitiannya diskriptif analitis, data yang dipergunakan data sekunder, yang dianalisis secara kualitatif. Hasil penelitian menunjukkan bahwa implikasi penerapan Undang-Undang Nomor 11 Tahun 2016 tentang Pengampunan Pajak (Tax Amnesty) dapat meningkatkan kepatuhan Wajib Pajak, dan berdasarkan implikasi tersebut SE Dirjen Pajak No. SE - 06/PJ/2017 seharusnya tidak hanya untuk tahun pajak 2017 saja, tetapi juga untuk tahun-tahun yang akan datang. Di samping itu perlu ada peraturan yang mengatur tentang pengawasan terhadap pelaksanaan hak Wajib Pajak.
\end{abstract}

Kata kunci : Penerapan, Tax Amnesty, Wajib Pajak. 


\begin{abstract}
In 2016, the government re-issue the Tax Amnesty policy as outlined in Law Number 11 Year 2016 on Tax Amnesty. The Tax Amnesty is expected to increase tax revenue in the short term through ransom payments, increase tax revenues over the long term through the expansion of taxation databases, increase taxpayer compliance, transition to a stronger and more just tax system, and encourage national tax reconciliation. In relation to this matter, to find out whether the program of Tax Amnesty Indonesia Year 2016 succeed or not, especially in increasing taxpayer compliance, it is necessary to do research on: "Implications Implementation of Law Number 11 Year 2016 on Tax Amnesty in Improving Taxpayer Compliance ". The problem to be discussed is how the implications of the implementation of Law Number 11 Year 2016 on Tax Amendment (Tax Amnesty) in improving taxpayer compliance? Based on these implications, then how should the taxation arrangements to come? Based on the problem, this type of research is normative juridical which will be studied with the approach of legislation, the analytical descriptive research specification, the data used secondary data, which analyzed qualitatively. The result of the research shows that the implication of the implementation of Law Number 11 Year 2016 on Tax Amnesty can improve Taxpayer compliance, and based on the implication of SE Dirjen Pajak No. SE - 06 / PJ / 2017 should not only be for the fiscal year 2017 alone, but also for the years to come. In addition, there should be a regulation that regulates the supervision of the implementation of taxpayers' rights.
\end{abstract}

Keywords: Implementation, Tax Amnesty, Taxpayer.

\title{
1. Pendahuluan.
}

Tax Amnesty atau Pengampunan Pajak pada tahun 2016 banyak diberitakan melalui media cetak maupun media elektronik. Hal ini disebabkan karena pemerintah pada tanggal 11 Juli 2016 mengeluarkan Undang-Undang Nomor 11 Tahun 2016 tentang Pengampunan Pajak. Keluarnya undang-undang tersebut disebabkan karena dalam kebijakan Anggaran Pendapatan dan Belanja Negara (APBN) tahun 2016 pemerintah menetapkan target penerimaan pendapatan negara sebesar Rp. 1.822,5 triliun dengan sumbangan dari sektor perpajakan sebesar $75 \%$ atau sebesar Rp. 1.360,2 triliun. Penetapan target dari sektor perpajakan tersebut relatif lebih besar jika dibandingkan dengan target dari dalam APBN tahun 2015 sebesar Rp. 1.294,3 triliun. Kenaikan tersebut karena tidak terlepas dari adanya upaya dari Presiden untuk membawa Indonesia berpindah strategi dari negara yang mengandalkan industri ekstraktif berbasis 
sumber daya alam menuju negara modern yang mengandalkan perpajakan sebagai motor utama pembangunan. ${ }^{1}$

Kebijakan pengampunan pajak (tax amnesty) tersebut menurut beberapa pengamat memiliki dampak positif sebagai berikut $:^{2}$

1. Meningkatkan penerimaan pajak dalam jangka pendek.

2. Meningkatkan kepatuhan pajak di masa yang akan datang.

3. Mendorong repatriasi modal atau asset.

Sehubungan dengan hal tersebut, untuk mengetahui apakah program Tax Amnesty Indonesia Tahun 2016 berhasil atau tidak, khususnya dalam meningkatkan kepatuhan wajib pajak, maka perlu dilakukan penelitian tentang : “Implikasi Penerapan Undang-Undang Nomor 11 Tahun 2016 tentang Pengampunan Pajak (Tax Amnesty) dalam Meningkatkan Kepatuhan Wajib Pajak". Adapun permasalahan yang akan dibahas adalah bagaimana implikasi penerapan Undang-Undang Nomor 11 Tahun 2016 tentang Pengampunan Pajak (Tax Amnesty) dalam meningkatkan kepatuhan Wajib Pajak ? Berdasarkan implikasi tersebut, maka bagaimana sebaiknya pengaturan perpajakan yang akan datang?

\title{
2. Tinjauan Pustaka.
}

\subsection{Pengertian dan Fungsi Pajak}

Pengertian pajak menurut P. J. A. Adriani adalah : ${ }^{3}$

\begin{abstract}
“iuran kepada negara (yang dapat dipaksakan) yang terhutang oleh yang wajib membayarnya menurut peraturan-peraturan dengan tidak mendapat prestasi kembali, yang langsung dapat ditunjuk, dan yang gunanya adalah untuk membiayai pengeluaran-pengeluaran umum berhubungdengan tugas negara untuk menyelenggarakan pemerintahan.',
\end{abstract}

\footnotetext{
${ }^{1}$ Kementerian Keuangan Republik Indonesia, Joko Tri Haryanto, pegawai Badan Kebijakan Fiskal Kementerian Republik Indonesia, halaman 1.

2 BEM UNDIP, “ Kajian Tax Amnesty”.
}

${ }^{3}$ Ibid, hlm. 2. 
Sedangkan menurut Soeparman Soemahamidjaja dalam disertasinya yang berjudul "pajak berdasarkan asas gotong royong", Universitas Pajajaran, Bandung, 1964 menyatakan bahwa : ${ }^{4}$

"pajak adalah iuran wajib, berupa uang atau barang, yang dipungut oleh penguasa berdasarkan norma-norma hukum, guna menutup biaya produksi barang-barang dan jasa-jasa kolektif dalam mencapai kesejahteraan umum."

Selanjutnya S. I. Djajadiningrat memberikan definisi yang lebih luas, yaitu : ${ }^{5}$

"pajak sebagai sesuatu kewajiban menyerahkan sebagian daripada kekayaan kepada negara disebabkan suatu keadaan, kejadian dan perbuatan yang memberikan kedudukan tertentu, tetapi bukan sebagai hukuman, menurut peraturan-peraturan yang ditetapkan pemerintah, serta dapat dipaksakan, tetapi tidak ada jasa balik dari negara secara langsung, untuk memelihara kesejahteraan umum."

Bertitik tolak dari definisi pajak yang diberikan oleh para ahli hukum pajak di atas, memberi kesan kepada kita bahwa pemerintah memungut pajak terutama atau semata-mata untuk memperoleh uang atau dana untuk membiayai pengeluaran-pengeluaran pemerintah, sehingga seakan-akan pajak hanya mempunyai fungsi sebagai sumber keuangan negara (budgetair), tetapi sebenarnya pajak mempunyai fungsi yang lebih luas, yaitu fungsi mengatur (reguler), dalam arti bahwa pajak itu dapat digunakan sebagai alat untuk mengatur atau melaksanakan kebijaksanaan negara dalam lapangan ekonomi (yang meliputi aspek makro, misalnya : stabilisasi harga, dan pertumbuhan ekonomi, serta aspek mikro, misalnya : akselerasi penghapusan dan "investment tax credit") dan sosial (misalnya pajak penjualan barang mewah, pengecualian kebutuhan pokok dari

\footnotetext{
${ }^{4}$ R. Soeparman Soemoharmidjaja dalam R. Santoso Brotodihardjo, Pengantar Ilmu Hukum Pajak, Eresco, Bandung, 1991, hlm. 2-5.

${ }^{5}$ S.I Djajadiningrat dalam S Munawir, Perpajakan, Liberty, Yogyakarta, 1990, hlm. 3.
} 
pengenaan pajak pertambahan nilai, dlsb. ${ }^{6}$ untuk itu maka perlu diketengahkan pengertian pajak ditinjau dari segi hukum yang dikemukakan oleh Rochmat Soemitro sbb : ${ }^{7}$

"pajak adalah perikatan yang timbul karena undang-undang yang mewajibkan seseorang (dalam pengertian baik natuurlijke persoon maupun recht persoon) yang memenuhi syarat-syarat yang ditentukan oleh undang-undang (tatbestand) untuk membayar sejumlah uang kepada kas negara yang dapat dipaksakan, tanpa mendapat imbalan yang secara langsung dapat ditunjuk, yang digunakan untuk membiayai pengeluaran-pengeluaran negara (rutin dan pembangunan) dan yang digunakan senagai alat (untuk mendorong atau menghambat) untuk mencapai tujuan di luar bidang keuangan negara".

Dari pengertian pajak dengan pendekatan hukum ini terlihat bahwa pajak bukan semata-mata untuk mencapai tujuan ekonomi, tetapi juga mempunyai tujuan regulasi. Dengan fungsi regulasinya pajak digunakan sebagai alat untuk mencapai tujuan-tujuan tertentu yang letaknya di luar bidang keuangan dan fungsi mengatur itu banyak ditujukan pada sektor swasta $^{8}$.

\subsection{Pengertian dan Latar Belakang Kebijakan Pengampunan Pajak} (Tax Amnesty).

Menurut ketentuan Pasal 1 angka 1 Undang-Undang Nomor 11 Tahun 2016 tentang Pengampunan Pajak, yang dimaksud dengan pengampunan pajak adalah :

"penghapusan pajak yang seharusnya terutang, tidak dikenai sanksi administrasi perpajakan dan sanksi pidana di bidang perpajakan, dengan cara mengungkap harta dan membayar uang tebusan sebagaimana diatur dalam undang-undang ini”.

\footnotetext{
${ }^{6}$ Gunadi, "Politik Perpajakan Indonesia", Berita Pajak No. 1375/Th.XXXI/15 Juli 1998, hlm. 39.

${ }^{7}$ Rochmat Soemitro, Pengantar Singkat Hukum Pajak, PT. Eresco, Bandung, 1992, hlm. 12.

${ }^{8}$ Munawir, Op. Cit, hlm. 5.
} 
Sedangkan menurut ketentuan Pasal 1 angka 2 Peraturan Menteri Keuangan Nomor 118/PMK.03/2016 tentang Pelaksanaan UndangUndang Nomor 11 Tahun 2016 tentang Pengampunan Pajak, yang dimaksud dengan pengampunan pajak adalah :

"penghapusan pajak yang seharusnya terutang, tidak dikenai sanksi administrasi perpajakan dan sanksi pidana di bidang perpajakan, dengan cara mengungkap harta dan membayar uang tebusan sebagaimana diatur dalam undang-undang Pengampunan Pajak".

Latar belakang dikeluarkannya kebijakan pengampunan pajak (tax amnesty) tahun 2016 di Indonesia adalah sebagai berikut :

a. Karena adanya keinginan menambah anggaran pembangunan dalam APBN, dan sektor migas yang menjadi primadona di masa orde baru sudah semakin menurun.

b. Pendanaan pembangunan lewat utang ataupun hibah dapat menciptakan kerawanan fiskal di masa mendatang serta memunculkan ketergantungan terhadap negara lain.

c. Jumlah pembayar pajak di Indonesia tergolong masih rendah dibandingkan negara maju (rendahnya tax ratio).

d. Terbatasnya kapasitas otoritas perpajakan terutama dalam mengawasi aktivitas perekonomian di sektor informal (underground economy) dan mencegah larinya modal (capital flight) ke luar negeri.

e. Terdapat banyak pihak yang mempunyai kekayaan yang berdasarkan penghindaran atau penggelapan pajak, baik yang tersimpan di dalam maupun luar negeri. Terdapat lebih dari Rp 3.000 triliun kekayaan WNI yang tersimpan di Singapura. Ini tidak berarti semua kekayaan tersebut terkait penggelapan.

\subsection{Pengaturan Kebijakan Pengampunan Pajak (Tax Amnesty) Tahun 2016.}

Kebijakan pengampunan pajak (tax amnesty) tahun 2016 dituangkan dalam Undang-Undang Nomor 11 Tahun 2016 tentang Pengampunan Pajak, yang pelaksanaannya diatur lebih lanjut dengan Peraturan Menteri Keuangan 
Nomor 118/PMK.03/2016 tentang Pelaksanaan Undang-Undang Nomor 11 Tahun 2016 tentang Pengampunan Pajak. Dalam ke dua peraturan tersebut dijelaskan bahwa : Wajib Pajak adalah orang pribadi atau badan yang mempunyai hak dan kewajiban perpajakan sesuai dengan ketentuan peraturan perundang-undangan di bidang perpajakan.

Setiap Wajib Pajak berhak mendapatkan pengampunan pajak. Pengampunan pajak tersebut diberikan kepada Wajib Pajak melalui pengungkapan harta yang dimilikinya dalam surat pernyataan, kecuali Wajib Pajak yang sedang :

a. dilakukan penyidikan dan berkas penyidikannya telah dinyatakan lengkap oleh Kejaksaan;

b. dalam proses peradilan; atau

c. menjalani hukuman pidana, atas Tindak Pidana di Bidang Perpajakan.

Pengampunan pajak yang diberikan meliputi pengampunan atas kewajiban perpajakan sampai dengan akhir tahun pajak terakhir, yang belum atau belum sepenuhnya diselesaikan oleh Wajib Pajak. Kewajiban perpajakan tersebut terdiri atas kewajiban:

a. Pajak Penghasilan; dan

b. Pajak Pertambahan Nilai atau Pajak Pertambahan Nilai dan Pajak Penjualan atas Barang Mewah.

Adapun tarif dan cara menghitung uang tebusan adalah sebagai berikut :

1. Tarif Uang Tebusan atas Harta yang berada di dalam wilayah Negara Kesatuan Republik Indonesia atau Harta yang berada di luar wilayah Negara Kesatuan Republik Indonesia yang dialihkan ke dalam wilayah Negara Kesatuan Republik Indonesia dan diinvestasikan di dalam wilayah Negara Kesatuan Republik Indonesia dalam jangka waktu paling singkat 3 (tiga) tahun terhitung sejak dialihkan, adalah sebesar:

a. $2 \%$ (dua persen) untuk periode penyampaian Surat Pernyataan pada bulan pertama sampai dengan akhir bulan ketiga terhitung sejak UndangUndang ini mulai berlaku; 
b. 3\% (tiga persen) untuk periode penyampaian Surat Pernyataan pada bulan keempat terhitung sejak Undang-Undang ini mulai berlaku sampai dengan tanggal 31 Desember 2016; dan

c. 5\% (lima persen) untuk periode penyampaian Surat Pernyataan terhitung sejak tanggal 1 Januari 2017 sampai dengan tanggal 31 Maret 2017.

2. Tarif Uang Tebusan atas Harta yang berada di luar wilayah Negara Kesatuan Republik Indonesia dan tidak dialihkan ke dalam wilayah Negara Kesatuan Republik Indonesia adalah sebesar:

a. $4 \%$ (empat persen) untuk periode penyampaian Surat Pernyataan pada bulan pertama sampai dengan akhir bulan ketiga terhitung sejak UndangUndang ini mulai berlaku;

b. $6 \%$ (enam persen) untuk periode penyampaian Surat Pernyataan pada bulan keempat terhitung sejak Undang-Undang ini mulai berlaku sampai dengan tanggal 31 Desember 2016; dan

c. $10 \%$ (sepuluh persen) untuk periode penyampaian Surat Pernyataan terhitung sejak tanggal 1 Januari 2017 sampai dengan tanggal 31 Maret 2017.

3. Tarif Uang Tebusan bagi Wajib Pajak yang peredaran usahanya sampai dengan Rp 4.800.000.000,00 (empat miliar delapan ratus juta rupiah) pada Tahun Pajak Terakhir adalah sebesar:

a. 0,5\% (nol koma lima persen) bagi Wajib Pajak yang mengungkapkan nilai Harta sampai dengan Rp 10.000.000.000,00 (sepuluh miliar rupiah) dalam Surat Pernyataan; atau

b. $2 \%$ (dua persen) bagi Wajib Pajak yang mengungkapkan nilai Harta lebih dari Rp 10.000.000.000,00 (sepuluh miliar rupiah) dalam Surat Pernyataan, untuk periode penyampaian Surat Pernyataan pada bulan pertama sejak Undang-Undang ini mulai berlaku sampai dengan tanggal 31 Maret 2017.

Penghitungan uang tebusan dilakukan dengan cara mengalikan tarif sebagaimana tersebut di atas dengan dasar pengenaan Uang Tebusan yang dihitung berdasarkan nilai Harta bersih yang belum atau belum seluruhnya 
dilaporkan dalam SPT PPh Terakhir, sedangkan untuk nilai harta bersih adalah merupakan selisih antara nilai harta dikurangi nilai utang.

\section{Metode Penelitian.}

\subsection{Jenis/Tipe Penelitian.}

Jenis/tipe penelitian ini adalah adalah yuridis normatif dengan pendekatan perundang-undangan, mengingat permasalahan yang dibahas dalam penelitian berpijak pada ketentuan hukum yang berlaku, yaitu Undang-Undang Nomor 11 Tahun 2016 tentang Pengampunan Pajak dan konsep hukum yang akan datang terkait dengan implikasi penerapan Undang-Undang Nomor 11 Tahun 2016 tentang Pengampunan Pajak.

\subsection{Spesifikasi Penelitian.}

Spesifikasi penelitian ini adalah deskriptif analistis, yaitu suatu penelitian yang dimaksudkan untuk memberikan gambaran tentang permasalahan melalui pengolahan dan penganalisaan data yang diperoleh untuk kemudian disimpulkan sesuai dengan hasil penelitian. Dalam penelitian ini peneliti berusaha memberikan gambaran dan pembahasan secara utuh mengenai implikasi penerapan Undang-Undang Nomor 11 Tahun 2016 tentang Pengampunan Pajak (Tax Amnesty) dalam meningkatkan kepatuhan Wajib Pajak, dan berdasarkan implikasi tersebut, maka bagaimana sebaiknya pengaturan perpajakan yang akan datang.

\subsection{Metode Pengumpulan dan Analisis Data.}

Data yang diperlukan dalam penelitian ini adalah data sekunder. Data tersebut diambil melalui studi kepustakaan. Hal ini dimaksudkan untuk mendapatkan landasan teoritis berupa pendapat-pendapat atau tulisan-tulisan para ahli hukum atau pihak-pihak lain yang berwenang guna memperoleh informasi baik dalam bentuk ketentuan-ketentuan formal ataupun data melalui naskahnaskah resmi yang ada, yang terdiri dari : 
1. Bahan Hukum Primer, berupa :

a. Undang-Undang Nomor 11 Tahun 2016 tentang Pengampunan Pajak.

b. Peraturan Menteri Keuangan Nomor 118/PMK.03/2016 tentang Pelaksanaan Undang-Undang Nomor 11 Tahun 2016 tentang Pengampunan Pajak.

2. Bahan Hukum Sekunder, berupa :

a. Hasil karya ilmiah para ahli yang relevan dengan materi penelitian.

b. Hasil penelitian yang relevan dengan materi penelitian

Data hasil penelitian tersebut kemudian akan dianalisis secara kualitatif yang dilakukan dengan cara meneliti dan mempelajari data sebagai sesuatu yang utuh kemudian dianalisis dan dikaitkan dengan teori-teori dan norma-norma yang ada relevansinya dengan permasalahan yang dibahas dalam penelitian ini.

\section{Hasil Penelitian \& Pembahasan.}

\subsection{Implikasi Penerapan Undang-Undang Nomor 11 Tahun 2016 tentang Pengampunan Pajak (Tax Amnesty) dalam Meningkatkan Kepatuhan Wajib Pajak.}

Program pengampunan pajak (tax amnesty) yang diatur dalam Undang-Undang Nomor 11 Tahun 2016 adalah program pengampunan pajak yang meliputi penghapusan pajak yang seharusnya terutang, penghapusan sanksi administrasi perpajakan, serta penghapusan sanksi pidana di bidang perpajakan atas harta yang diperoleh pada tahun 2015 dan sebelumnya yang belum dilaporkan dalam SPT, dengan cara melunasi seluruh tunggakan pajak yang dimiliki dan membayar uang tebusan. Yang dapat memanfaatkan program pengampunan pajak (tax amnesty) adalah :

1. Wajib Pajak Orang Pribadi.

2. Wajib Pajak Badan.

3. Wajib Pajak yang bergerak di bidang Usaha Mikro Kecil dan Menengah (UMKM).

4. Orang Pribadi atau Badan yang belum menjadi Wajib Pajak. 
Pelaksanaan program pengampunan pajak (tax amnesty) dibagi dalam 3 (tiga) periode, yaitu :

1. Periode I : dari tanggal 1 Juli 2016 sampai dengan 30 September 2016.

2. Periode II: dari tanggal 1 Oktober 2016 sampai dengan 31 Desember 2016.

3. Periode III : dari tanggal 1 Januari 2017 sampai dengan 31 Maret 2017.

Besarnya tarif dan cara menghitung uang tebusan dalam pengampunan pajak (tax amnesty) dalam Undang-Undang Nomor 11 Tahun 2016 diatur dalam Pasal 4 sampai dengan Pasal 7, sebagai berikut :

1. Tarif uang tebusan atas harta yang berada di dalam wilayah Negara Kesatuan Republik Indonesia atau harta yang berada di luar wilayah Negara Kesatuan Republik Indonesia yang dialihkan ke dalam wilayah Negara Kesatuan Republik Indonesia dan diinvestasikan di dalam wilayah Negara Kesatuan Republik Indonesia dalam jangka waktu paling singkat 3 (tiga) tahun terhitung sejak dialihkan, adalah sebesar :

a. $2 \%$ (dua persen) untuk penyampaian surat pernyataan pada periode $\mathrm{I}$

b. $3 \%$ (tiga persen) untuk penyampaian surat pernyataan pada periode II; dan

c. $5 \%$ (lima persen) untuk penyampaian surat pernyataan pada periode III.

2. Tarif uang tebusan atas harta yang berada di luar wilayah Negara Kesatuan Republik Indonesia dan tidak dialihkan ke dalam wilayah Negara Kesatuan Republik Indonesia adalah sebesar :

a. $4 \%$ (empat persen) untuk penyampaian surat pernyataan pada periode I;

b. $6 \%$ (enam persen) untuk penyampaian surat pernyataan pada periode II; dan 
c. $10 \%$ (sepuluh persen) untuk untuk penyampaian surat pernyataan pada periode III.

3. Tarif uang tebusan bagi Wajib Pajak yang peredaran usahanya sampai dengan Rp 4.800.000.000,00 (empat miliar delapan ratus juta rupiah) pada tahun pajak terakhir adalah sebesar :

a. $0,5 \%$ (nol koma lima persen) bagi Wajib Pajak yang mengungkapkan nilai harta sampai dengan Rp10.000.000.000,00 (sepuluh miliar rupiah) dalam surat pernyataan; atau

b. $2 \%$ (dua persen) bagi Wajib Pajak yang mengungkapkan nilai harta lebih dari Rp10.000.000.000,00 (sepuluh miliar rupiah) dalam surat pernyataan, untuk periode penyampaian surat pernyataan pada 1 Juli 2016 sampai dengan tanggal 31 Maret 2017.

Besarnya uang tebusan dihitung dengan cara mengalikan tarif sebagaimana tersebut di atas dengan dasar pengenaan uang tebusan. Dasar pengenaan uang tebusan dihitung berdasarkan nilai harta bersih yang belum atau belum seluruhnya dilaporkan dalam SPT PPh terakhir. Nilai harta bersih merupakan selisih antara nilai harta dikurangi nilai utang.

Hasil pelaksanaan pengampunan pajak (tax amnesty) periode I adalah sebagai berikut : penerimaan uang tebusan Rp 97,2 triliun. Dari jumlah tersebut, deklarasi harta mencapai $\mathrm{Rp} 4.500$ triliun dan repatriasi $\mathrm{Rp}$ 137 triliun. Sementara dari sisi wajib pajak, peserta non-UMKM jumlahnya mencapai 61.873 wajib pajak atau sekitar 16 persen. Sedangkan yang UMKM mencapai 14.338 wajib pajak, wajib pajak badan 76.211. Dari wajib pajak badan tersebut, wajib pajak non-UMKM 236.934, wajib pajak UMKM 54.319. Sehingga total ada 367.464 Wajib Pajak. ${ }^{9}$

Hasil pelaksanaan program pengampunan pajak (tax amnesty) periode II, Berdasarkan data dasboard DJP, nilai deklarasi harta berdasarkan Surat Pernyataan Harta (SPH) telah menembus angka Rp 4.296 triliun. Komposisi nilai pernyataan berdasarkan SPH itu antara lain,

${ }^{9}$ Direktorat Jenderal Pajak (DJP) Kementerian Keuangan (Kemenkeu), Liputan6.com, 3 Oktober 2016 
deklarasi dalam negeri masih memiliki porsi paling besar yaitu mencapai Rp 3.143 triliun. Untuk deklarasi luar negeri sebesar Rp 1.013 triliun dan dana repatriasi sebesar Rp 141 triliun. Adapun jumlah uang tebusan berdasarkan SPH yang disampaikan mencapai Rp 103 triliun. Rincianya, untuk wajib pajak badan Usaha Mikro, Kecil dan Menengah (UMKM) sebesar Rp 338 miliar, wajib pajak badan non-UMKM sebesar 12,4 triliun. Kemudian untuk wajib pajak orang pribadi non-UMKM sebesar Rp 85,8 triliun dan wajib pajak orang pribadi UMKM sebesar Rp 4,74 triliun. Sementara, realisasi berdasarkan Surat Setoran Pajak (SSP) yang diterima telah mencapai Rp 107 triliun. Rinciannya, uang tebusan sebesar Rp103 triliun, pembayaran tunggakan sebesar Rp 3,06 triliun dan pembayaran bukti permulaan (bukper) sebesar Rp 739 miliar. ${ }^{10}$

Hasil pelaksanaan program pengampunan pajak (tax amnesty) periode III berdasarkan data dashboard tax amnesty, total harta yang dilaporkan tersebut terdiri dari deklarasi harta dalam negeri Rp 3.676 triliun dan deklarasi harta luar negeri mencapai Rp 1.031 triliun. Sementara penarikan dana dari luar negeri (reptriasi) mencapai Rp 147 triliun, tebusan Rp 114 triliun, ditambah dengan tunggakan dan bukper jadinya Rp 135 triliun, dan pembayaran tunggakan Rp 18,6 triliun. Adapun total tebusan tersebut terdiri dari orang pribadi non-UMKM sebesar Rp 91,1 triliun, dan orang pribadi UMKM sebesar Rp 7,73 triliun. Kemudian, uang tebusan dari badan non-UMKM Rp 14,6 triliun, dan badan non-UMKM Rp 656 miliar. $^{11}$

Dari data tersebut di atas menunjukkan bahwa program pengampunan pajak (tax amnesty) dapat meningkatkan kepatuhan wajib pajak.

\footnotetext{
${ }^{10}$ Direktorat Jenderal Pajak (DJP) Kementerian Keuangan (Kemenkeu), Liputan6.com, 1 Januari 2017

${ }^{11}$ Direktorat Jenderal Pajak (DJP) Kementerian Keuangan (Kemenkeu), Liputan6.com, 1 April 2017
} 


\subsection{Pengaturan Perpajakan yang Akan Datang Berdasarkan Implikasi} Penerapan Undang-Undang Nomor 11 Tahun 2016 tentang Pengampunan Pajak (Tax Amnesty) dalam Meningkatkan Kepatuhan Wajib Pajak.

Dalam pelaksanaan pengampunan pajak (tax amnesty), untuk mempertahankan kepatuhan Wajib Pajak, Menteri Keuangan telah menyelenggarakan manajemen data dan informasi, dan menteri, wakil menteri, pegawai kementerian keuangan, serta pihak lain yang berkaitan dengan pelaksanaan pengampunan pajak (tax amnesty), dilarang membocorkan, menyebarluaskan, dan/atau memberitahukan data dan informasi yang diketahui atau diberitahukan oleh Wajib Pajak kepada pihak lain. Di samping itu data dan informasi yang disampaikan Wajib Pajak dalam rangka pengampunan pajak (tax amnesty) digunakan sebagai basis data perpajakan Direktorat Jenderal Pajak, dan tidak dapat diminta oleh siapapun atau diberikan kepada pihak manapun berdasarkan peraturan perundang-undangan, kecuali atas persetujuan Wajib Pajak sendiri.

Direktur Jenderal Pajak dalam meningkatkan pengawasan terhadap Wajib Pajak juga terus mengembangkan pengawasan Wajib Pajak melalui system informasi, yang dituangkan dalam Surat Edaran Direktur Jenderal Pajak Nomor SE - 49/PJ/2016 tentang Pengawasan Wajib Pajak Melalui Sistem Informasi Direktur Jenderal Pajak, yang menyatakan bahwa Direktorat Jenderal Pajak mengembangkan sistem informasi agar dapat meningkatkan pengawasan Wajib Pajak secara efektif, efisien, dan berkesinambungan.

Sedangkan untuk meningkatkan kepatuhan Wajib Pajak, Direktur Jenderal Pajak mengeluarkan Surat Edaran Nomor SE - 06/PJ/2017 tentang Strategi Peningkatan Kepatuhan Wajib Pajak dan Penetapan Target Rasio Kepatuhan Wajib Pajak Tahun 2017.

Dari uraian tersebut, terlihat bahwa berdasarkan implikasi penerapan Undang-Undang Nomor 11 Tahun 2016 tentang Pengampunan Pajak (Tax Amnesty) dalam meningkatkan kepatuhan Wajib Pajak, Direktur Jenderal 
pajak telah mengeluarkan Surat Edaran Direktur Jenderal Pajak Nomor SE - 49/PJ/2016 tentang Pengawasan Wajib Pajak Melalui Sistem Informasi Direktur Jenderal Pajak dan Surat Edaran Nomor SE - 06/PJ/2017 tentang Strategi Peningkatan Kepatuhan Wajib Pajak dan Penetapan Target Rasio Kepatuhan Wajib Pajak Tahun 2017. Namun demikian hal tersebut masih kurang, seharusnya surat edaran tersebut bukan hanya untuk tahun 2017 saja, tetapi juga untuk tahun-tahun yang akan dating. Di samping itu menurut Safri Nurmantu sebagaimana dikutip oleh Sony Devano dan Siti Kurnia Rahayu dalam bukunya Perpajakan, Konsep, Teori dan Isu, menyatakan bahwa : "Kepatuhan wajib pajak yaitu kepatuhan perpajakan yang didefinisikan sebagai suatu keadaan dimana wajib pajak memenuhi semua kewajiban perpajakan dan melaksanakan hak perpajakannya." ${ }^{~} 12$ Sedangkan Norman D. Nowak sebagaimana dikutip oleh Mohammad Zain dalam bukunya yang berjudul Manajemen Perpajakan, menyatakan bahwa kepatuhan Wajib Pajak adalah: ${ }^{13}$

"Suatu iklim kepatuhan dan kesadaran pemenuhan kewajiban perpajakan, tercermin dalam situasi dimana:

a.Wajib Pajak Paham atau berusaha untuk memahami semua ketentuan perundang-undangan perpajakan.

b.Mengisi formulir pajak dengan lengkap dan jelas.

c.Menghitung pajak yang terhitung dengan benar.

d.Membayar pajak yang terutang tepat pada waktunya. “

Menurut Mardiasmo dalam bukunya yang berjudul Perpajakan ada 2 macam kepatuhan wajib pajak, yang terdiri dari :

1. Kepatuhan pajak materiil.

2. Kepatuhan Pajak Formil.

Kepatuhan pajak materiil adalah kepatuhan terhadap norma-norma yang menerangkan antara lain keadaan, perbuatan, peristiwa hukum yang dikenai pajak (objek pajak), siapa yang dikenakan pajak (sumber), berapa besar pajak yang dikenakan (tarif), segala sesuatu tentang timbul dan

\footnotetext{
${ }^{12}$ Sony Devano dan Siti Kurnia Rahayu, Perpajakan, Konsep, Teori dan Isu, Prenada Media, Jakarta, 2006, halaman 10.

${ }^{13}$ Mohammad Zain, Manajemen Perpajakan, Salemba Empat, Jakarta, 2007, halaman 31.
} 
hapusnya utang pajak, dan hubungan hukum antara pemerintah dan Wajib Pajak. Contoh: Undang-undang Pajak Penghasilan.

Kepatuhan Pajak Formil adalah kepatuhan terhadap norma-norma yang mengatur tentang bentuk/tata cara untuk mewujudkan hukum materiil menjadi kenyataan (cara melaksanakan hukum pajak materiil), antara lain : tata cara penyelenggaraan (prosedur) penetapan suatu utang pajak, hak-hak fiskus untuk mengadakan pengawasan terhadap Wajib Pajak mengenai keadaan, perbuatan dan peristiwa yang menimbulkan utang pajak, kewajiban Wajib Pajak misalnya menyelenggarakan pembukuan/ pencatatan, dan hak-hak Wajib Pajak misalnya mengajukan keberatan dan banding. Contoh: Ketentuan Umum dan Tata Cara Perpajakan. ${ }^{14}$

Berdasarkan pendapat para ahli terlihat bahwa kepatuhan Wajib Pajak dipengaruhi oleh beberapa faktor yaitu kondisi sistem administrasi perpajakan suatu negara, pelayanan pada Wajib Pajak, penegakan hukum perpajakan, pemeriksaan pajak, pengawasan pelaksanaan peraturan perundang-undangan perpajakan dan tarif pajak. Jika faktor kepatuhan Wajib Pajak bisa diperbaiki, diharapkan Wajib Pajak lebih termotivasi dalam memenuhi kewajiban perpajakannya, sehingga dalam membuat peraturan yang terkait dengan peningkatan kepatuhan Wajib Pajak tidak hanya mengatur tentang pengawasan Wajib Pajak dalam melaksanakan kewajibannya saja, tetapi juga pengawasan terhadap Wajib Pajak dalam melaksanakan haknya, dan aparatur perpajakan dalam melaksanakan tugasnya sesuai dengan peraturan perundang-undangan. Pengawasan terhadap aparatur perpajakan dalam melaksanakan tugasnya sesuai dengan peraturan perundang-undangan telah diatur dalam Peraturan Menteri Keuangan Nomor 63/PMK.09/2016 tentang Perubahan atas Peraturan Menteri Keuangan Nomor 54/PMK.09/2008 tentang Komite Pengawas Perpajakan. Dalam Pasal 1 ayat (1) Peraturan Menteri Keuangan tersebut dijelaskan bahwa : Komite Pengawas Perpajakan adalah komite non struktural yang bertugas membantu Menteri Keuangan dan bersifat

${ }^{14}$ Mardiasmo, Perpajakan, Andi, Yogyakarta, 2003, halaman 5. 
mandiri dalam melakukan pengawasan terhadap pelaksanaan tugas Instansi Perpajakan.

\section{Simpulan dan Saran.}

4.1. Simpulan.

Implikasi penerapan Undang-Undang Nomor 11 Tahun 2016 tentang Pengampunan Pajak (Tax Amnesty) dapat meningkatkan kepatuhan Wajib Pajak, dan berdasarkan implikasi tersebut untuk meningkatkan kepatuhan Wajib Pajak yang akan datang, SE Dirjen Pajak No. SE - 06/PJ/2017 seharusnya tidak hanya untuk tahun pajak 2017 saja, tetapi juga untuk tahun-tahun yang akan datang. Di samping itu perlu ada peraturan yang mengatur tentang pengawasan terhadap pelaksanaan hak Wajib Pajak.

4.2. Saran.

Program pengampunan pajak (tax amnesty) tahun 2016 jangan hanya dipergunakan sebagai sasaran target di tahun2016 saja, tetapi harus dijadikan sebagai landasan untuk melakukan reformasi perpajakan secara menyeluruh ke depannya. Di samping itu pemerintah harus dapat meningkatkan kemampuan mengawasi dan memungut pajak, sehingga program pengampunan pajak (tax amnesty) ini bukan menjadi program rutin yang akan dilakukan pemerintah di masa yang akan datang.

\section{DAFTAR PUSTAKA}

\section{a. Buku :}

Brotodihardjo, R. Santoso. Pengantar Ilmu Hukum Pajak. Eresco : Bandung, 1991.

Devano, Sony \& Siti Kurnia Rahayu. Perpajakan : Konsep, Teori dan Isu. Prenada Media Group : Jakarta, 2006.

Mardiasmo. Perpajakan. Andi : Yogyakarta, 2003.

Soemitro, Rochmat. Pengantar Singkat Hukum Pajak. Eresco : Bandung, 1992.

S Munawir. Perpajakan. Liberty : Yogyakarta, 1990. 
Zain, Mohammad. Manajemen Perpajakan. Salemba Empat : Jakarta, 2007.

b. Makalah :

BEM UNDIP. “ Kajian Tax Amnesty”.

Gunadi. "Politik Perpajakan Indonesia". Berita Pajak No. 1375/Th.XXXI/15 Juli 1998.

Kementerian Keuangan Republik Indonesia, Joko Tri Haryanto, Pegawai Badan Kebijakan Fiskal Kementerian Republik Indonesia.

Liputan6.com.” Hasil Tax Amnesty Periode I". 3 Oktober 2016. . “Hasil Tax Amnesty Periode II". 1 Januari 2017. . "Hasil Tax Amnesty Periode III". 1 April 2017.

\section{c. Peraturan Perundang-Undangan :}

Undang-Undang Nomor 11 Tahun 2016 tentang Pengampunan Pajak.

Peraturan Menteri Keuangan Nomor 63/PMK.09/2016 tentang Perubahan atas Peraturan Menteri Keuangan Nomor 54/PMK.09/2008 tentang Komite Pengawas Perpajakan.

Surat Edaran Direktur Jenderal Pajak Nomor SE - 49/PJ/2016 tentang Pengawasan Wajib Pajak Melalui Sistem Informasi Direktur Jenderal Pajak

Surat Edaran Direktur Jenderal Pajak Nomor SE - 06/PJ/2017 tentang Strategi Peningkatan Kepatuhan Wajib Pajak dan Penetapan Target Rasio Kepatuhan Wajib Pajak Tahun 2017 